\title{
Two Perspectives on E-Learning Design: A Synopsis of a U. S. and a European Analysis
}

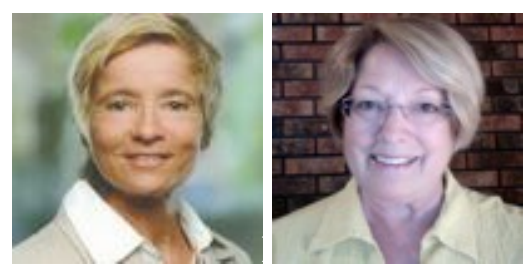

Stefanie A. Hillen ${ }^{1}$ and Melodee Landis ${ }^{2}$

1University of Agder, Norway, 2University of Nebraska at Omaha, USA

\section{Abstract}

This article seeks to examine e-learning design arising from two educational traditions: the United States of America and Europe. The research question is: Broadly, what kinds of pedagogy, instructional design models, or didactical models are established and proposed for e-learning design on the two continents? Two researchers examined multiple articles and texts in an effort to discern the prominent approaches in their respective regions. The analysis is tripartite: First, the educational philosophies, which have guided e-learning design on each continent, will be presented; second, specific theories about learning influencing e-learning design will be discussed; and finally, elearning design, which arises from innovative instructional strategies, will be investigated. The resulting analysis brings to the surface not only how the values that underpin e-learning development in each region differ but also how specific perspectives influence the respective fields. The researchers acknowledge these differences but also remark on the historic and contemporary symbiosis that has endured even in this relatively new field of e-learning.

Keywords: E-learning design; instructional design; educational philosophies; mediadidactics; general didactics 


\section{Introduction}

For those who undertake the design of e-learning experiences, navigating through the multiple approaches and models can be daunting. It is hoped that, by studying the various approaches and comparing them across the continents, we can gain some insight into the overarching schools of thought that have been driving e-learning design. Thus, the purpose of this paper is to compare how two analysts view e-learning design in their respective regions: the United States and Europe.

The analysts focus on those interactions among students, teachers, and the subject matter respectively that are supported, enabled, or guided by electronic technology. This includes both synchronous and asynchronous approaches.

To gather data, the authors each conducted extensive searches of existing periodical literature and consulted numerous texts on instructional technology working to identify the underlying theory and guiding principles used by e-learning designers in their respective spheres of operation. Nearly two hundred publications, electronic and print, were examined using a grounded theory approach to analyze the data. The U.S. information was analyzed by a scholar experienced in instructional design; the European material was analyzed by an expert in media and comparative education. These two perspectives are evident in the reports and will be considered in the resulting analysis.

\section{Framework for the Analysis of European and U.S. E-Learning} Design

To compare the approaches and processes used in the two countries, the levels of research activity articulated by Arthur Ellis and J effrey Fouts in their book Research on Educational Innovations (1997) were helpful. An adaptation of their levels of research, spanning from philosophies to theories to practice, has been created to organize this study. Since broad educational philosophies have served as the basis for instructional design in both regions, they will be discussed first. Then the content in each region will approximate a general to specific approach as follows:

U.S.

- How educational philosophies have guided e-learning design in the U.S.

- $\quad$ Specific theories and models influencing e-learning design in the U.S.

- E-learning design arising from innovative instructional strategies in the U.S. 


\section{Europe}

- How educational philosophies have guided e-learning design in Europe

- Specific theories and models influencing e-learning design in Europe

- E-learning design arising from innovative instructional strategies in Europe

As the authors applied this tripartite structure, they found they needed to adapt to the specific educational traditions and philosophies of the data they uncovered. This led to subtopics that are themselves revealing. It must be stressed that these analyses are made from the viewpoints of each of the authors in the hope they will shed some light on general approaches used on each continent.

\section{Philosophies and Broad Learning Theories Beneath E- Learning Design}

Many principles guiding today's e-learning design spring from Europe's and America's common heritage over the centuries. While these schools of thought are not specific to e-learning, they have deeply influenced all instructional design. From the philosophical roots of idealism, realism, and existentialism established by such philosophers as Plato and Aristotle through the existentialism and empiricism of Sartre and Kant, three broad learning theories appear most commonly in the literature: behaviorism, cognitivism, and constructivism. It is assumed that most readers are familiar with the tenets of these philosophies so this analysis will concentrate on how they appear to manifest in elearning design.

\section{E-Learning Design in the U.S.}

\section{How Educational Philosophies have Guided E-Learning Design in the U.S.}

In the United States, the progression of e-learning design in recent decades appears to have roughly progressed from behaviorism to cognitivism to constructivism. Early on, computers were used as a supplemental way to reinforce teaching. First efforts stressed behaviorist approaches such as drill and practice activities and quizzes corrected by the computer. It was common to present expository slides that used images and simple language to introduce the learner to content, then to follow that with quiz questions calling for the user to select an answer. Correct answers prompted rewards such as rudimentary images or sounds. Incorrect responses were rejected or looped the learner back to the expository slides to cover the content again. Out of this evolved more 
sophisticated, independent learning systems. These systems sought to differentiate learning by branching to the most appropriate next step after each response (Squire, J ohnson, \& Bichelmeyer, 1998).

The behaviorist and cognitivist approaches were largely co-mingled in early e-learning. Content was logically organized (cognitivist) and learners were led through the material using operant conditioning techniques along the way (behaviorist). The rise of the "information processing" approach complemented the capability of the computer as an information management system (McLeod, 2008).

Cognitivists were impressed with the computer's power to more vividly illustrate material through graphic images and highly structured simulations/situations. Discussion groups were also introduced during this period though conversations were often confined to specific questions. Most early e-learning courses were highly structured along content lines. In most online courses, learners were guided through the same path of learning in order for them to acquire the knowledge as organized and prescribed by the e-learning designer(s). No differences were made between learners' needs or prerequisites. Today, this phenomenom is captured by the idea of individualization (personalization) in e-learning.

The constructivist push came as more flexible mind-mapping tools and social networking possibilities became prevalent. Some designers broke from the strictures of traditional cognitivism to become more learner-centered using individual and group tools for digesting and organizing information. The constructivist approach is still evolving but generally involves more activities that call for the learner to research, organize, and communicate as they learn, often choosing their own sources and products along the way. Though most e-learning today is still highly structured by content, some designers are seeking to provide alternate routes to achieve higher levels of autonomy, comprehension, and critical analysis.

The move away from defining learning as knowledge acquisition and organization to the development of functional skills and judgment has deepened what American scholars require of e-learning designers. No doubt, technology's power is somewhat responsible for this deeper agenda.

\section{Specific Theories and Models Influencing E-Learning Design in the U.S.}

The lines separating educational philosophies, learning theories, and planning models are often difficult to discern. There are, however, a few theoretical approaches that are noteworthy because they are frequently cited by those developing modern e-learning design models. 


\section{Situationist perspective.}

As Erica de Vries (2003, p. 161) states, "Today, different theoretical perspectives on learning and instruction co-exist partly inspired by technological developments." To the behaviorist, cognitivist, and constructivist perspectives, she adds the "situationist perspective".

The situationist perspective on learning highlights the idea that the learned knowledge has to be used in real life (Brown, Collins, \& Duguid, 1989). According to the proponents of the situationist perspective, authentic activities, that is, the ordinary practices of a domain culture rather than traditional classroom activities, are needed for knowledge to be constructed in a form that will be exploitable in the future (Lave \& Wenger, 1991, p. 163). The tenets of situationism are popular in some e-learning design models that appear in American literature.

\section{Chaos theory.}

One other broad approach that bears discussion is chaos theory. Educational designers with this perspective perceive the full complexity of the learning environment, the instructor(s), the content, and the learners (Lorenzen, 2008). The intent is to remind designers that it is virtually impossible to plan for all variables in a learning situation and trying to control them may in fact inhibit learning. Supporters of chaos theory join the situational learning advocates in promoting the design of learning activities that resemble real-world experiences (Gollub \& Solomon, 1996). Simulations, gaming, problem-based learning, and project-based learning are receiving increased attention by e-learning designers who ascribe to the chaos perspective.

\section{Information processing theory.}

Many e-learning designs still hold to the "teaching as delivery" model when designing elearning programs (de Vries, 2003). These designers consider learning to be the intake of information through the well-designed presentation of information using media designed to enhance the perception process (p. 160). One perspective on this approach is the "elaboration theory" developed by Reigeluth $(1987,1999)$, who proposes three organizations for designing content:

- the conceptual elaboration sequence (when there are many related concepts to be learned),

- the theoretical elaboration sequence (when there are many related principles to be learned), and

- the simplifying conditions sequence (when a task of at least moderate complexity is to be learned). 


\section{Cognitive load.}

This theory warns that overloading the brain with too much information can be counterproductive (Sweller, 1999). This is at odds with some of the extravagant multimedia productions and excessive hyperlinking. The dual processing theory by Schneider and Shiffrin (1977) portrays the mind as having two modes of functioning, automatic and controlled, and has become the basis for research on whether and how multimedia can enhance learning. For example, research by Mayer and Moreno (1998) found that learners could assimilate words and pictures better when using their dual processing (auditory and visual) capabilities. It seems comprehension is enhanced when the words are presented auditorily rather than visually. Clark and Mayer's studies (2011) and those of others (Baylor \& Kim, 2005; J ones, et al., 1994) have used new research on perception and retention to establish many other reliable principles for multimedia design.

\section{Cooperative learning theory.}

The large body of cooperative learning research by the J ohnson brothers $(1988,1994)$ and others have had a significant impact on the design of elearning as well. As the internet has become more ubiquitous, designers have incorporated more instructorlearner, learner-learner, and expert-learner interaction through the use of discussion boards, group work, and chat functions.

\section{Generative learning theory.}

The Cognition and Technology Group at Vanderbilt (1991, NA) called for designs that respond to their generative learning theory. This perspective acknowledges the importance of building on the past learning experiences of the individual learner by providing learning situations that call for experimentation, creativity, and openmindedness. The group's work calls for situated cognition, anchored in real-life replications (Cognition and Technology Group at Vanderbilt, 1990, 1991). One example was the Adventures of J asper Woodbury, a series of adventures provided on an optical video disc (Nipper, ND) with realistic video and specialized technology that challenge students to analyze data, define problems, formulate strategies, and implement solutions.

\section{Instructional design models.}

The most common term used in the United States to describe a prescriptive, methodical approach to planning teaching and learning experiences is instructional design (ID). Many instructional design models work to classify and encompass nearly all variables involved in the instructional process prior to instruction. The field is so broad that many American institutions of higher education offer entire programs of study in instructional design. Gustafson and Branch (2002) offer a general description that seeks to encompass the many forms of the process: "Instructional design is a system of procedures for developing education and training programs in a consistent and reliable 
fashion. Instructional design is a complex process that is creative, active and iterative" (p. 17).

The systematic procedures developed by such theorists as Smith and Ragan (1999), Dick et al. (2004), and Morrison, Ross, and Kemp (2004) are complex and rigorous; these models work to guide the designer to anticipate almost all possibilities, before and during instruction.

Gustafson and Branch (1997) discovered that instructional design models have at least four components: analysis of the setting and learner needs; design of a set of expectations for an effective, efficient and relevant learner environment; development of all learner and management materials; and evaluation of results of the development (formative and summative) (p. 8f).

In keeping with behaviorist and cognitivist philosophies, there is the underlying assumption that one can anticipate learners' behaviors or cognitive processes and predesign their learning. ID proponents claim the method produces a well-organized, systematic course of study using the technology. While much of the work is done ahead of the presentation of a course, teacher reflection and adjustment is also encouraged throughout the process.

ID is not without critics, however. Some contend that design of some types of instruction before experiencing the learning environment and experimenting with the actual learners is premature (Hokanson \& Miller, 2009). Others maintain systematic instructional design creates study that is inflexible and directed to superficial learning goals (Prensky, 2001; Rowland, 1992). Another obvious drawback cited by critics is the amount of time and effort involved in approaching design this way.

\section{Rapid prototyping.}

Another approach that has been gaining traction among those designing for electronic media is that of rapid prototyping. This process works to address the shortcomings of traditional instructional design by sketching a preliminary framework and then dynamically gathering information as instruction occurs.

The process is described as 'iterative' since it advocates early testing of activities, often starting with low tech' experiments before moving to other media (Piskurich, 2006). Richard Culatta (2011) has sketched the difference between classic instructional design and rapid prototyping (see Table 1).

This trial and error method of development appears to be especially relevant for learning programs that rely on animation, artificial intelligence, and complex interactions between the material and the learner. Those who produce advanced digital learning materials attest to the speed and cost-saving advantages of the model (Creative Industries Research Institute, 2007). 
Table 1

Classic Instruction Design and Rapid Prototyping

\begin{tabular}{|l|l|}
\hline Classic design & Rapid prototyping \\
\hline 1. concept definition & 1. concept definition \\
\hline 2. requirements definition & $\begin{array}{l}\text { 2. implementation of a skeletal } \\
\text { system }\end{array}$ \\
\hline 3. preliminary design & 3. user evaluation and concept \\
\hline 4. detailed design & $\begin{array}{l}\text { 4. implementation of refined } \\
\text { requirements }\end{array}$ \\
\hline 5. code implementation & $\begin{array}{l}\text { 5. user evaluation and concept } \\
\text { refinement }\end{array}$ \\
\hline 6. test and acceptance & $\begin{array}{l}\text { 6. implementation of refined } \\
\text { requirements }\end{array}$ \\
\hline $\begin{array}{l}\text { 7. [griping because you now realize that } \\
\text { there was something that got left out } \\
\text { back in step 2] }\end{array}$ & 7. [etc., etc., in a continuous cycle] \\
\hline
\end{tabular}

\section{E-Learning Design Arising from Innovative Instructional Strategies in the U.S.}

Some advocates of e-learning design base their methods on innovative or researchproven instructional strategies. The last few decades have been an exciting time of experimentation stimulated by the promise of emerging digital and Web-based technologies.

\section{Problem-based learning.}

The work of David H. Jonassen has promoted the use of technology applications as 'mind tools'. He points to the many ways blogging, concept-mapping, presentations, image creation, and social media can be used to inspire individual reflection and analysis as well as group discussion and collaboration. Jonassen sees power in organizing reality-based problems for learners to attack. He feels learning is deepest when students are part of investigatory teams in which they have a defined role (Howland, et al., 2011; J onassen, 2011, 2006, 2000; J onassen, Carr, \&Yueh, 2007).

\section{Virtual worlds, field trips.}

More and more virtual spaces are being created to provide simulations of authentic learning experiences that are being sought by those stressing reality-based, situated learning. From macro-contexts to micro-worlds, designers are working to create online environments where learners can create alter egos (avatars), explore exotic places, and interact with others from around the world (Schank, 1997). As examples, the application of 'Second Life' can be named. Such an approach is offered by the Seminole County Public Schools (SCPC, 2014). "Virtual worlds might be useful tools in online teaching because of their ability to engage students in interactions to build a sense of 
community in classes ..." (Baker et al., 2009). Moreover, virtual worlds create a learning environment where experiences can be made which are otherwise too dangerous or too time or cost intensive, or they can change pupils' established roles by choosing an avatar's role, which might lead to different or expanded learning experiences.

\section{Gaming and simulations.}

There is a growing community of e-learning designers who are convinced that gaming and simulations are especially suited to today's youthful learners (e.g., Prensky, 2001). They label many of the traditional e-learning design methodologies as static approaches that disregard how contemporary youth process information, using click games, apps, and simulations. They defend the glitzy, rapid-paced, thrilling effects as effective ways to motivate modern learners. Some of these designers provide suggestions for design principles as well (Deterding, 2013). Cohen's (2011) approach is the gamification of education. He stresses that online social games may be poised to replace textbooks in schools. Examples he refers to are the PBS KIDS's interactive whiteboard games, which teach basic subjects to very young children, and the Learning Company's hugely popular historical learning game, The Oregon Trail (Cohen, 2011, p. 16). An approach named 'Quest to Learn' (Thomas \& Brown, 2011) is used for example in New York City public charter schools, which has practically eliminated textbook-based learning and largely replaced it with game-based learning. The key for successful learning is seen in rule based learning systems, in which players actively participate, and use strategic thinking to make choices, solve complex problems, seek content knowledge, receive constant feedback, and consider the point of view of others (Cohen, 2011, p. 17). This applies for adult and professional training situations too.

\section{Communities of learning.}

Pursuant to existing research on cooperative learning, many designers have exploited the tools of social networking, often calling for online groupings or communities of learners. Course management systems and Web tools provide ample opportunities for using chats, discussion boards, Facebook-like sites, or blogs in online courses. The notion of providing a community of learners and guided discovery advocated by Ann Brown and others has given rise to the creation of virtual learning spaces that encourage constant and effective collaboration in online learning activities (Brown \& Campione, 1994). Current research focuses on effective strategies raising questions on technical and social prerequisites to build and support these kinds of learning communities (Charalambos, Michalinos, \& Chamberlain, 2004; Carlén \& Jobring, 2005; Palloff \& Pratt, 2007).

A survey about K-12 online learning in 2007 came to one general conclusion: The trends of online learning which can be observed in postsecondary education that approximately three million students are enrolled in fully online courses or blended courses will follow in private as well as in public primary and secondary education too (Picciano \& Seaman, 2007). A follow up study in 2009 confirmed this assumption. The result was that the overall number of $\mathrm{K}-12$ students engaged in online courses show a 
47\% increase since 2005-2006. In addition, the respondents report that online learning is meeting the specific needs of a range of students, from those who need extra help and credit recovery to those who want to take Advanced Placement and college-level courses (Picciano \& Seaman, 2009).

It should be noted that some of the above approaches were abandoned in the last decade in response to the political pressures of the No Child Left Behind (NCLB) movement. Some e-learning designers have expressed concern with the goals of the NCLB, claiming that they regress teaching and learning to more shallow learning outcomes.

\section{E-Learning Design in Europe}

\section{How Educational Philosophies have Guided E-Learning Design in Europe}

\section{General didactics.}

Before focusing on e-learning models, one should address the general didactics models and didactics itself, which has a long tradition in Europe in the context of education. This school of thought is having a strong influence on e-learning approaches, too. The very first time the concept was mentioned was 500, B.C.E., in ancient Greece. The word "didactics" is derived from the Greek word didaskein and can be translated as "the art of teaching", whereas the word didaskaleion (ca. 1127) means the location to show something (to someone).

A didactic model is a theoretical framework for the analysis and planning of didactic activities, actions, and interaction in institutionalized and non-institutionalized educational contexts. A didactical model is striving for the comprehensive enlightenment of the prerequisites, opportunities, and limitations of teaching and learning. A didactical model is often connected to one or several specific traditions in the philosophy of science (J ank \& Meyer, 2010).

Central to didactics is the triangulation among the student, the teacher, and the content. Hence, it is called the didactic triangle (Figure 1). In most of the didactic approaches, specifically the newer ones, the reflective role of the teacher is central to the teaching process (Westbury, et al., 2000). The reflective activity requires that the teacher select, depict, and enrich the content (matter) of the given curriculum, for example, with the help of a didactical analysis (Klafki, 2002). The aim of a didactical analysis is to make the content meaningful to the learner. That is, the teacher is responsible for stressing topics that, from the teacher's reflective perspective, will be essential to the students' present and future lives. This is the so-called professional teacher's liberty as it stresses the teacher's duty to act in a self-reliant fashion. In a nutshell, the reflective teacher has 
to make meaning out of the subject matter for the benefit of students' learning and development.

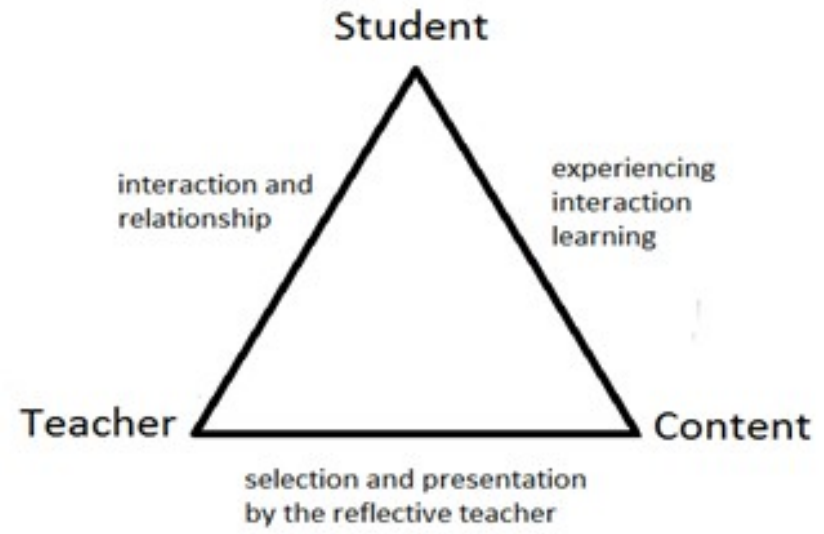

Figure 1. The didactic triangle.

There are over 13 different approaches (families) to didactics (Kron, 2008; Terhart, 2009; Kammerl, 2011) that can be subdivided into several models and concepts. Because of the emphasis on online teaching and learning in this paper, we will only address those approaches, models, and concepts that relate most directly to technologybased teaching and learning.

The use of information technology (IT) is considered more than just an additional or alternative teaching approach in education. Currently, IT is an integral part of most students' literacy: a meaningful element of their everyday life. Hence, it affects the matter of Bildung in a society (von Humboldt, 2000). The term Bildung is briefly translated as "formation" and is strongly related to the idea of didactics. Westbury et al. (2000) explain that this formation implies both the forming of the personality into a unity as well as the product of this formation and the particular "formedness" that is presented by the person. Thus, there is a need to critically reflect on how the opportunities and risks of using technology affect the overall development of the individual. The central question emerges as "What is the role of technology in teaching and learning?"

There are established models of general didactics, which include the use of technology as an integrated or framing element in teaching. An example is the Hamburg model, which is a normative, descriptive model. The Hamburg model, seen below (as translated by Gundem, 2011), takes into account students' need to be free to evaluate critically the influences of the system they are part of. It stresses media as a mediation variable named MV (see inner circle of the model, Figure 2), that is, technology as an auxiliary tool (MV mediation variable) for supporting or controlling the teaching and learning processes. 


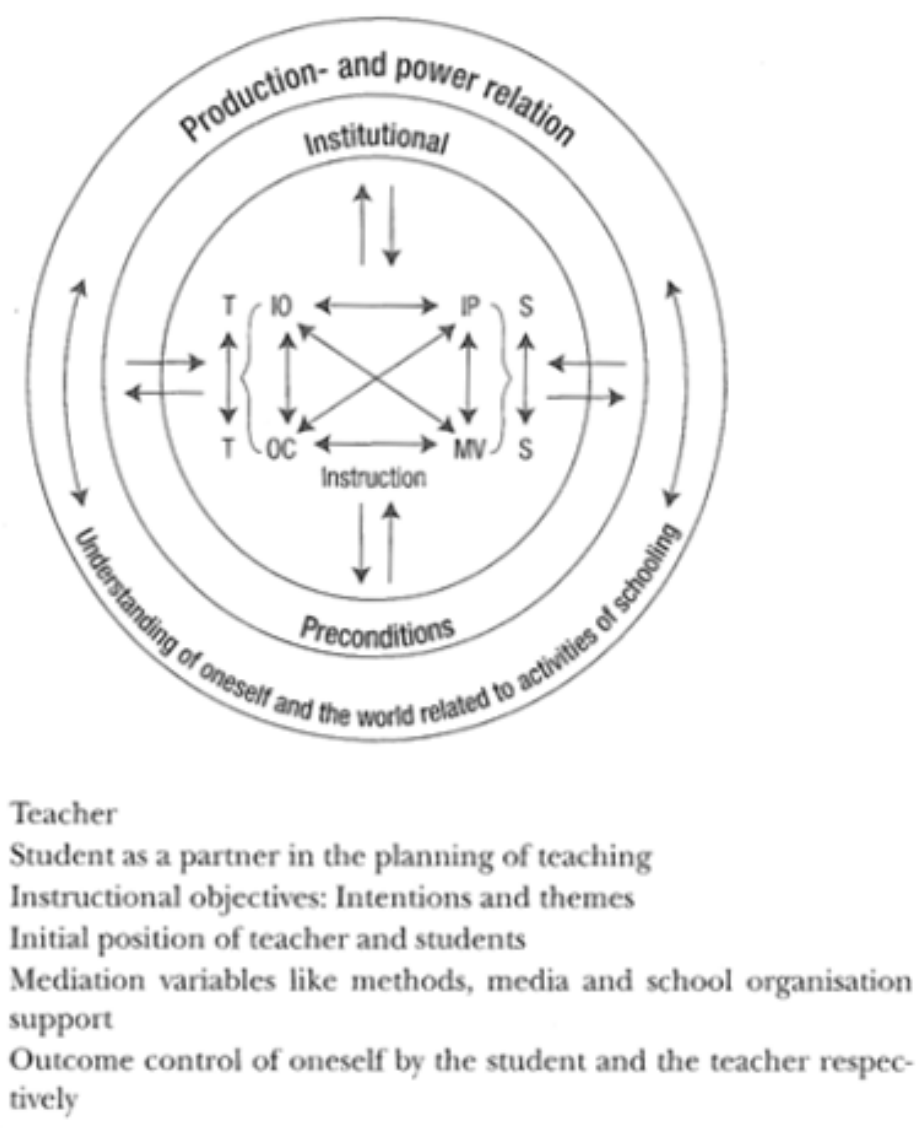

Figure 2. Hamburg model (Schulz, 1997; translated by Gundem, 2011).

The student ( $\mathrm{S}$ ) is seen as a partner in the planning of the instruction and the evaluation of the learning outcomes (OC). The model respects the institutional preconditions as well. The elements, methods, content, media, and intentions are seen as interrelated.

A related model in Norway is called 'relasjonsmodellen' (Bjørndal \& Lieberg, 1978), which is used in adult education (Lodgaard, et al., 2001). Newer publications stress the meaning of the relational model as a framework for schooling (Østerud \& Knudsen, 2009, p. 41) and criticize the missing support for objectives in teaching. The relational model asks the teacher to fill that gap. A general criticism of didactic approaches compared to instructional design approaches are that they do not respect enough the perspectives of the curriculum (Gundem, 2011) and the educational system. That is, didactic models are primarily designed from an individual's perspective (micro level) in teaching and learning. Other Scandinavian approaches to media didactics focus more on the subject-related application of media as a tool for teaching and learning (Iversen, et al., 2002). 


\section{Specific Theories and Models Influencing E-Learning Design in Europe}

\section{Media didactics.}

In Europe, one can say that media didactics established its own discipline in the 1960s. The learning theory model of Heimann, Otto, and Schulz (1965) was one milestone followed by the later Hamburg model (Schulz, 1997). Media didactics can be described as a function and a consequence of applying media in teaching and learning processes (Issing, 1987, cited in Kron \& Sofos, 2003, p. 48). An alternative classification by Tulodziecki and Herzig (2010, p. 110) describes media didactics as the relationship between instruction and the use of media. Hillen (Figure 3) depicts an overview of the different approaches to media didactics: teaching tool approach, learning tool approach, building block concept (elements), learning environment concept, and finally the systems concept, which is inspired by the approaches of programmed instruction. One perspective, of the systems approach, is based on the work of teams of instructional designers. The teachers themselves decide its usage. It is expected that students show a receptive and reactive learning behavior. Self-regulated learning is possible. The learning environment concept is primarily based on the idea of learning with learning management systems. Self-regulated and self-directed learning is expected and supported by the learning environment concept (Tulodziecki \& Herzig, 2004, p. 112ff).

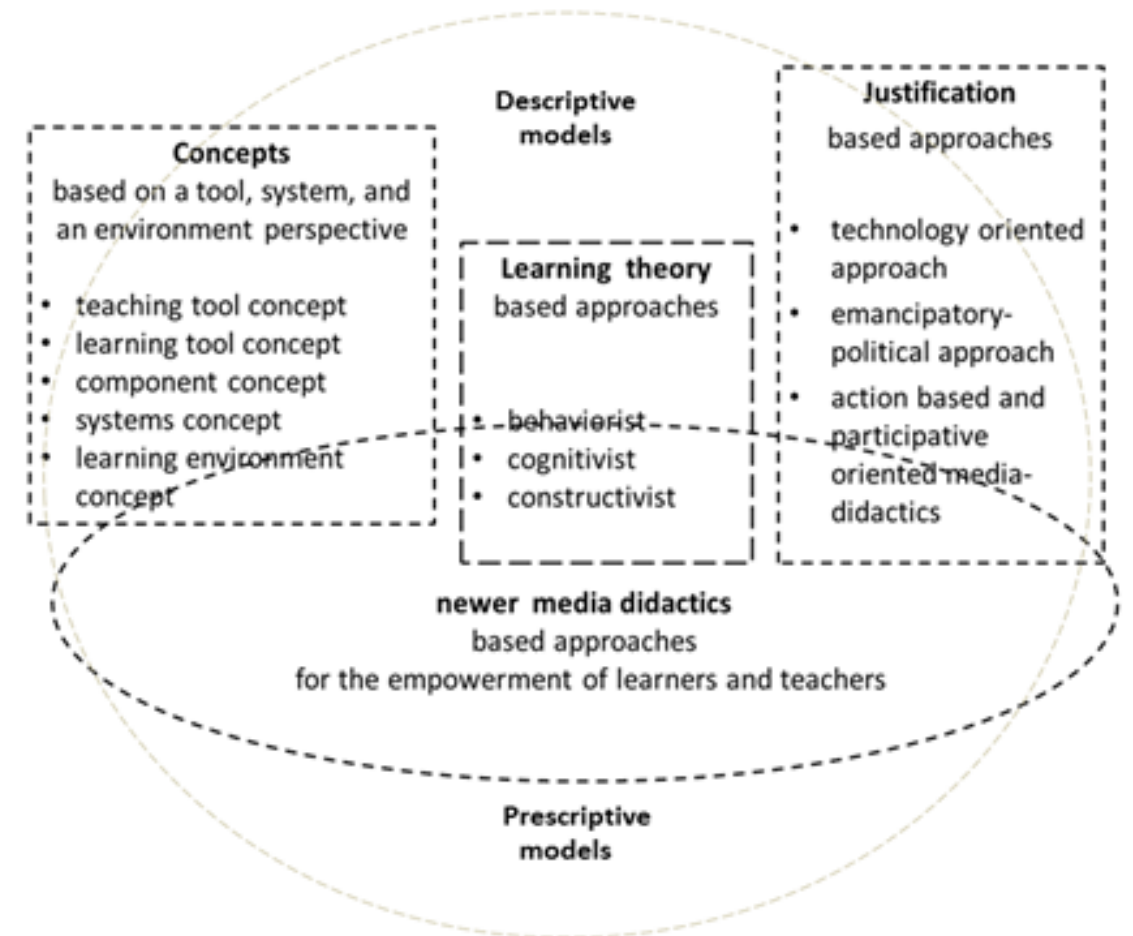

Figure 3. Approaches in media didactics (Hillen, 2013). 
Another approach offers a classification of learning theories for media didactics orientation: behaviorist, cognitivist, and constructivist (Kron \& Sofos, 2003, p. 54; Tulodziecki \& Herzig, 2010, p. 128). The newer media didactics approaches are based on a constructivist paradigm, which calls for the proper use of media for the acquisition of knowledge in a meaningful way (Kron \& Sofos, 2003). An additional approach was derived to offer justification for applying technology in educational and didactical contexts. The justification classification can be divided into a) technology oriented approach, b) emancipatory-political approach and, finally, c) the action based and participatory oriented media didactics (Kron \& Sofos, 2003, p. 55).

Another European trend in media didactics is the so-called didactic design (Gissel, 2011, p. 17; Ballstaedt, 1997; Kerres, 2006). This has a strong affinity to the instructional design approach discussed above. One explanation is that media based learning needs explicit, advance planning for the application of media. Educators seek to prescribe the opportunities for interaction between the learner and the media, which has to be determined a priori (Kerres, 2006).

This tendency to construct planning oriented models for e-learning is common (see section below e.g., DO-ID) while neglecting the reflection of the (media-)didactics models. Media-didactic models inherently support paradigms for planning, conducting, and reflecting on Bildung. Despite newer developments, Tulodziecki (2005) criticizes the missing theoretical foundations in research and development in the context of media didactics. A statement from Haft (1988), even if it's over twenty years old, depicts the contrast between the two approaches: "Online-technology is speeding up but didactics is creeping slowly behind".

To summarize, media didactics comprises a variety of approaches that exist parallel to each other. Media didactics, its models and approaches, are influenced by general didactics, instructional design models, as well as by trends like didactic design that make the influences of instructional design models literally visible.

It has to be said that, because of the discussed trends above, one cannot generalize what the educational strategies in e-learning are. Instead, three general trends are chosen to reflect the diversity and breadth of strategies for e-learning and e-learning design one can find in Europe.

\section{E-Learning Design Arising from Innovative Instructional Strategies in Europe}

\section{Student empowerment - a descriptive model.}

As described above, new approaches in media didactics are working for the empowerment of learners and teachers (Tulodziecki \& Herzig, 2004, 2010). Tulodziecki (2005) characterizes this as a transition from the use of technology as an auxiliary tool to that of complex learning environments (see Figure 2). The learning environment approach should support learners' interaction with complex tasks and problems. A 
curriculum/ educational initiative in Switzerland exemplifies the empowerment of students and teachers using information technology (IT). They name it the potential by teaching with information and communication technology (ICT). It focuses on skills like computer literacy as well as on media education (SFIB, 2007).

The theoretical framework for these powerful or rich learning environments is manifold. The well-known learning theories (behaviorist, cognitivist, and constructivist) are used as well as the didactical approaches named "action-based" (Jank \& Meyer, 2010) and approaches that are participation-based (Kron \& Sofos, 2003) are developed and applied as well (Tulodziecki, 2005).

In addition, the concept of situated learning appeared in the European educational landscape of learning environments (Mandl, et al., 2002) that was influenced, for example, by the Anglo-American cognitive flexibility theory, anchored instruction, and the cognitive apprenticeship approach (Straka \& Macke, 2002).

\section{Didactic design and the model of configuration-oriented media didactics - a prescriptive model.}

A prescriptive model of didactic design includes the development of an environment that supports learning from its conceptualizing phase until its evaluation. This constructivist oriented approach by Kerres (translated from Kerres "gestaltungsorientierte Mediendidaktik", 2005, 2007) is seeking to use new, digital media to add value to classical forms of transfer and learning (Ballstaedt, 1997). The configuration-oriented media didactics model offers a framework, which justifies the use of new media even if more effort is needed. The following principles guide the model (Kerres \& de Witt, 2004; Kerres, 2007, p. 173):

- A project always needs to address an educational and formative problem.

- The question is not to find and apply the ultimate best didactic method.

- An educational project has to be adjusted to the parameters of the didactic field, that is, the given situation (prerequisites).

- The specific media-configured learning approach must add value compared to other already existing solutions.

This framework is based on the opinion that the one ideal solution for media based teaching does not exist, but that a situational selection of the instructional means, for example media, is useful. The determining parameters are, for example, the media and method competencies of the teachers and students, the expectations of the people involved, societal trends, and so on (Kerres, 2005, 2007). Kerres' approach follows the prescriptive idea for planning and conducting teaching with media. This assumes that specific learning results or learning events can be accomplished under different circumstances and conditions. 
Applying this assumption one has to conclude that formation can be fabricated but this is orthogonal to the principles of a 'geisteswissenschaftliche' (humanistic) education, which states that Bildung (formation) cannot be created, configured, or induced. This is what makes the approach of Kerres inconsistent with the ideal of Bildung.

\section{The decision oriented instructional design model, Do-ID - a prescriptive model.}

The decision oriented instructional design model is an example of a model influenced by instructional design theory and project management approaches (see Figure 4). The decision-oriented instructional design model (Do-ID) seen below performs a prescriptive function. As in Niegemann et al. (2008, p. 85), this has the advantage of making contradictions in e-learning design visible as well as making general research gaps visible.

The Do-ID model can be described as a tool for systematic, project oriented planning for multimedia learning environments.

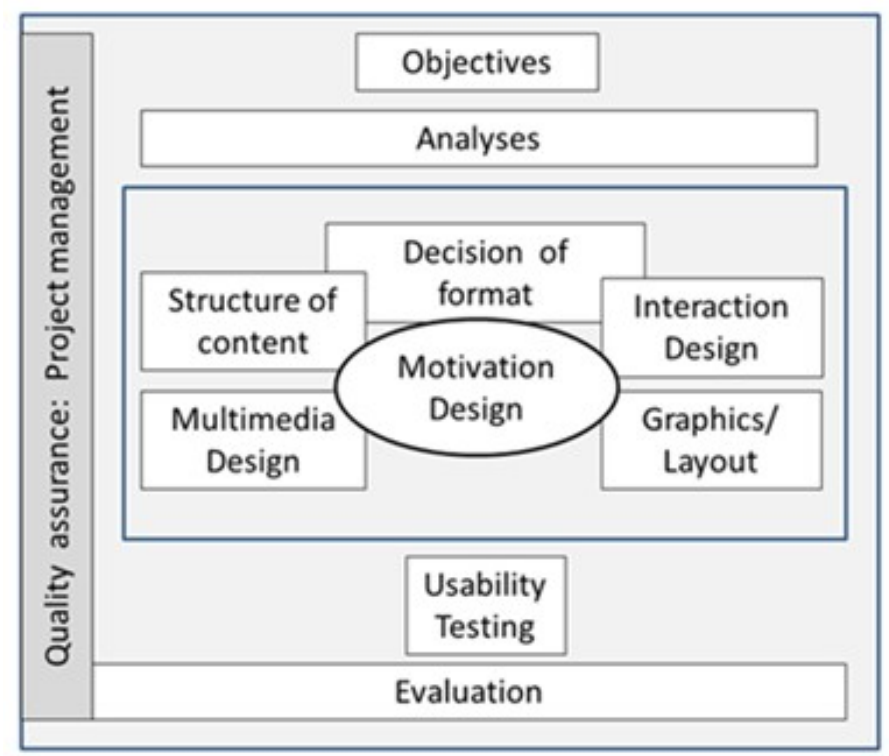

Figure 4. DO-ID model (in orientation to Niegemann, et al., 2008, p. 85).

The Do-ID model combines ideas of ID and project management to address concerns of quality management and evaluation. The model contains six decision components in which several design elements are to be addressed. These are the format, the structuring of the content, the selection and combination of media, the motivation of students, and the layout, the user interface with the software and hardware as well as respect for ethical constraints. The design decisions are interdependent. 
The Do-ID model contributes to quality management by defining the objectives of the multimedia product. It also can be used for a critical reflection respecting its complexity within the whole.

Formats for e-learning design are expository, explorative, constructive, and the communicative e-learning system (Schüpbach, et al., 2003). The didactic structure reflects the learning theories used for the course.

\section{Analysis of the Two Educational Analyses}

\section{Distinct Characteristics}

It must be stressed that a comprehensive analysis over time is not in the scope of this paper, which nevertheless will not neglect the view of historical educational paradigms influencing the ongoing development of e-learning instruction.

\section{Roots, influences, and developments.}

The U.S. perspective started from a classical and instructional technology point of view (Oakes \& Lipton, 1999), whereas the European is derived from a didactics and later a media-didactics perspective (Klafki, 2002; Schulz, 1997). While both approaches share some ground related to the educational philosophies, the Norwegian report goes more deeply into the abstract notion of Bildung, an intense valuing of the formation of the individual. While American theorists are devoted to the importance of personal learning programs, their arguments appear to lack ardor when compared to the European shared value of Bildung.

The U.S. analysis shows some of the newest approaches as advocating a more severe departure from existing learning theory. Advocates of chaos theory tenets and major shifts to accommodate the digital generation call for techniques using simulation in virtual worlds to gaming. Newer approaches in the European analysis appear to retain a relationship with traditional theories from the didactics and Bildung traditions even if some liberties are taken with prescriptive and ID models. Even quite different prescriptive and descriptive models, however, are trending toward similar objectives: the empowerment of the learner applying media for learning purposes.

\section{Affinities Between the Analyses of Both Regions}

\section{Learning theories, methods, and the learners' growth.}

Both regions acknowledge the power of behaviorism, cognitivism, and constructivism as guiding principles with constructivism moving to the fore in many recent models. The concepts of active (Howland, et al., 2011) or participant-based learning (Kron \& Sofos, 
2003) are currently stressed in both arenas. Even as the instructional design models have become more diverse in both countries, the underlying paradigms have undergone changes from design of strongly behavioristic oriented programs (e.g., drill and practice) to cognitivist and constructivist oriented ones. Both describe an affinity for more authentic, situation-based learning.

It is apparent that European and American traditions have influenced each other. The analyses show that specific U.S. e-learning design theories presented have become a meaningful part in rich or complex learning environments in Europe. Likewise, the record of Europe's open learning experience has provided a legacy for newer American distance learning programs.

Both analyses describe planning and reflecting approaches which seek to consider the many complexities of a given learning environment prior to delivery of instruction. Though both traditions have struggled between prescriptive and descriptive models, over time both have opened up to the importance of the empowerment of learners and teachers. Careful analysis and flexibility are encouraged to better insure quality management and to maximize the learner's growth.

\section{Acknowledgement of the challenges and potentials for e-learning.}

Both analyses recognize the potential and the challenges inherent in e-learning. They work to respond to research results from other disciplines (e.g., direct teaching, rapid prototyping, chaos theory, project management) to improve the development and implementation of e-learning. Several emerging trends in e-learning, such as the globalization of distance education, the availability of informal learning opportunities, the ubiquity of cyberspace connections around the world, and the presence of technology in everyday life and learning have unleashed the control of e-learning design from professional instructional designers. With or without them, learners are gaining access to all forms of information and learning experiences in an unstructured, personalized fashion. It has become the task of designers to deal with learners with wildly different entry skills and learning needs. Modern online capacities have challenged e-learning designers to develop drastically new learning-teaching strategies such as communities of learners, gaming, artificial intelligence, and global collaboration. Happily, both continents are simultaneously seeing the importance of providing communication between the students and others (J ohnson \& J ohnson, 1994; Fogarty, 1999, p. 76; Schüpbach, 2003).

\section{'Multi-theory' approach.}

Both traditions have started to acknowledge that a 'multi-theory' approach serves better the needs of learners and teachers than striving after a single best e-learning design approach or single e-learning theory. Approaches exist in parallel - choose the best. 


\section{Conclusions and Outlook}

This overview of e-learning design on the two continents has tried to capture the broad patterns of the two regions and educational traditions. While both reports acknowledge common guiding educational philosophies (behaviorism, cognitivism, and constructivism), differing political pressures and values have influenced the progression of e-learning design approaches in each region. Recent e-learning design in the United States appears to have been guided by goals related to learners' competencies in basic skills and professional readiness. Europe appears to have retained a central allegiance to the development for the whole individual (Bildung).

These statements are over-generalizations, of course. We acknowledge that there are strong movements on each continent that swim against the current. For example, there is evidence that Europe is now moving to standardize competencies (similar to the NCLB movement in America) and the U.S. is rediscovering the importance of skills beyond testable competencies. Perhaps this paradox is worth noting. One continent may be at odds with the other at a given time but, interestingly, the swings of the pendulum appear ultimately responsive to each other.

There are trends common to both regions that are worth discussion. Both reports note that in early e-learning planning technology was used as a relatively minor tool to support existing teaching and learning processes used to master content goals. As testing became more dominant in the U.S., exposing the weaknesses of existing instructional design, and as the power of the Internet to free the learner to pursue individual curiosities and learning paths became undeniable, instructional designing began to shift from more prescriptive modes of e-learning design to more spontaneous, collaborative, and action-based learning.

The wave of online learning swept over from higher education to secondary and primary education in both continents. In the U.S., this trend is visible in public and in private education as well. This applies for European education too, whereas in European education systems this differentiation has not played a very important role in the past (Debande, 2004). This is due to the fact that in most of the European educational systems public schools were predominant. This is based on the idea of free access to schools and on the idea of 'Bildung for all', even though a change can be observed by the arrival of the 'accountability concept' in the public sectors in Europe.

On both continents, e-learning models have emerged which acknowledge the power of technology to fundamentally change how and what learning takes place. These models seem to adopt a multi-theory approach to design. What's more, these models identify expanded goals and competencies resulting from modern societal demands and the unbridled opportunities offered by the Web. Many new media design models include the provision of an online infrastructure that provides content information, multiple resources, collaborative opportunities, and sometimes even alternate paths for achieving objectives. What's more, the re-commitment to more critical thinking and 
problem solving is manifest in the refinement of situational learning approaches (problem-based learning, case studies, simulations, etc.).

In most programs, the role of the e-learning designer or e-teacher is increasingly complex. Providing a balance between identifying clear central objectives and designing activities that are open enough to respond to autonomous learning needs is a tricky prospect. Yet, it appears to be the only choice if we are to embrace the remarkable potential of electronic access to unlimited data and expertise. One can recognize a trend toward a higher level of customized learning (personalization, individualization, contextualization, and adaptive learning). Student involvement is often required throughout to promote autonomy and transfer. Collaboration and communication are no longer centered on the teacher and e-learning design must acknowledge this. It is obvious that e-learners can now pursue their own paths with or without the instructor and the challenge is for the design to allow for a variety of learning paths for the benefit of individual learners.

Thus, we can assume that the e-learning landscape will become even more diverse. Some learners are not ready for learning environments where they are asked to take charge of their own growth. Some professions and disciplines rely on the mastery of critical content and competencies. Thus, there will continue to be prescriptive, contentcentered design needs in the e-learning environment. Still, we must recognize the importance of newer forms of e-learning design and their potential to meet essential human and societal needs.

The identification of a historical framework has helped the researchers to reflect on how elearning design has developed over recent decades and how newer approaches have emerged in both regions. It is hoped that the observance of common emerging trends has contributed to a better understanding of the broad scope of e-learning design. Recognizing the parallelism of newer multi-theory design options undergirded by shared educational philosophies but differing cultural ethics may help designers to operate in our newly global design environment. More importantly, it is hoped that increased awareness of newer modes of design might help to avoid limiting design options to simplistic, prescriptive patterns that have, in the past, limited opportunities for ever-expanding learners' and teachers' needs. 


\section{References}

Baker, S. C., Wentz, R. K., \&Woods, M. M. (2009). Using virtual worlds in education: Second Life as an educational tool. Teaching of Psychology, 36(1), 59-64. Retrieved from http:// edtc6325teamone2ndlife.pbworks.com/f/VitruaWorldsSLl+.pdf

Ballstaedt, S. P. (1997). Wissensvermittlung. Die Gestaltung von Lernmaterial [Transfer of knowledge. The creation of learning material; in German]. Weinheim: Beltz Psychologie Verlags Union.

Baylor, A. L., \& Kim, Y. (2005). Simulating instructional roles through pedagogical agents. International J ournal of Artificial Intelligence in Education, 15(1), 95115.

Bjørndal, B., \& Lieberg, S. (1978). Nye veier i didaktikken?: en innføring i didaktiske emner og begreper [New ways towards didactics?: an introduction in topics and concepts of didactics; in Norwegian]. Oslo: Aschehoug.

Brown, A. L., \& Campione, J .C. (1994). Guided discovery in a community of learners. In K. McGilly (Ed.), Classroom lessons: Integrating cognitive theory and classroom practice (pp. 229-270). Cambridge, MA: MIT Press/Bradford Books.

Brown, J . S., Collins, A., \& Duguid, P. (1989). Situated cognition and the culture of learning. Educational Researcher, 18(1), 32-41.

Carlén, U., \&J obring, O. (2005). The rationale of online learning communities. International J ournal of Web Based Communities, 1(3), 272-295.

Charalambos , V., Michalinos, Z., \& Chamberlain, R. (2004). The design of online learning communities: Critical issues. Educational Media International, 41(2), 135-143.

Clark, R., \& Mayer, R. (2011). E-learning and the science of instruction: Proven guidelines for consumers and designers of multimedia learning. New York: Pfeiffer.

Cognition and Technology Group at Vanderbilt (1990). Anchored instruction and its relationship to situated cognition. Educational Researcher, 19(6), 2-10.

Cognition and Technology Group at Vanderbilt (1991). Technology and the design of generative learning environments. Educational Technology J ournal, 31(5), 3440.

Cognition and Technology Group at Vanderbilt (NA). Cognitive flexibility theory. Retrieved from http:// otec.uoregon.edu/learning_theory.htm 
Cohen, A. M. (2011). The gamification of education. The Futurist, 45(5), 16-17. Retrieved from

http:// search.proquest.com.library.sheridanc.on.ca/ docview/ 884627174?accou ntid=3455

Creative Industries Research Institute (2007). Introduction to rapid prototyping. AUT University. Retrieved from http:// www.ici.qut.edu.au/researchdomains/designfuture.jsp

Culatta, R. (2011). Rapid prototyping. Instructional Design.org. Retrieved from http:// www.instructionaldesign.org/models/rapid_prototyping.html

Debande, O. (2004). Icts and the development of elearning in europe: The role of the public and private sectors. European J ournal of Education, 39(2), 1465-3435. http://dx.doi.org/ 10.1111/j.1465-3435.2004.00175.x

Deterding, S. (2013). Gameful design for learning. T+D, 67(7), 60-63.

de Vries, E. (2003). Educational technology and multimedia from a cognitive perspective: Knowledge from inside the computer, onto the screen and into our heads? In H. van Oostendorp (Ed.), Cognition in a digital world (pp. 155-174). Mahwah, NJ : Lawrence Erlbaum Associates

Dick, W.O., Carey, L., \& Carey, J . O. (2004). Systematic design of instruction. Boston, MA: Allyn \& Bacon.

Ellis, A. K., \&Fouts, J. T. (1997). Research on educational innovations (2nd ed.). Princeton J unction, N.J .: Eye on Education.

Fogarty, R. (1999). Architects of the intellect. Educational Leadership, 57(3), 76-78.

Gissel, S. T. ( 2011). Mediedidaktik i teori og praksis [Media didactics: theory and practice, in Danish]. København: Academia Forlag.

Gollub, J ., \& Solomon, T. (1996). Chaos theory. In K. A. Ranson (Ed.), Academic American encyclopedia (V. 4, pp. 282- 283). Danbury, CT: Grolier Incorporated.

Gundem, B. B. (2011). Europeisk Didaktikk. Tenkning og viten [European didactics. Thinking and knowledge; in Norwegian]. Oslo: Universitetsforlaget.

Gustafson, K. L., \& Branch, R. M. (1997). Survey of instructional development models ( $3^{\text {rd }}$ ed.). Syracuse, NY: ERIC Clearinghouse of Information and Technology.

Gustafson, K. L., \& Branch, R. M. (2002). What is instructional design? In R. A. Reiser \&J. V. Dempsey (Eds.), Trends and issues in instructional design and technology (pp. 16-25). Columbus: OH, Merrill Prentice Hall. 
Haft, H. (1988). Einführung: 'Neue Medien und Sozialisation - Die Technik rennt, die Forschung humpelt [Technology is running, research is hobbling]. Unterrichtswissenschaft, 16(4), 2-6.

Heimann, P., Otto, G., \& Schulz, W. (1965). Unterricht-Analyse und Planung [Teaching, analysis and planning]. Hannover: Schroedel.

Hillen, S. (2013). What can research in technology and learning teach media didactics? In K. Beck \& O. Zlatkin-Troitschanskaia, (Eds.), From diagnostics to learning success. Proceedings in vocational education and training (pp. 101-113). Rotterdam: Sense.

Hokanson, B., \& Miller, C. (2009). Role-based design: A contemporary framework for innovation and creativity in instructional design. Educational Technology, 49(2), 21- 28.

Howland, J ., J onassen, D.H., \& Marra, R.M. (2011). Meaningful learning with technology (4th ed.). Columbus, OH: Merrill/ Prentice-Hall.

Issing, L. (Ed)(1987). Medienpädagogikk im Informationszeitalter [Media education in the information age; in German]. Weinheim. Deutscher Studienverlag.

Iversen, G. B., Asmussen, J ., Carlsen, B. B., \&Nelson, C. (2002). Mediedidaktik [Media didactics; in Danish]. Frederiksberg: Dansklærerforeningen Forlag.

J ank, W., \& Meyer, H. (2010). Didaktiske Modeller [Didactic models; in Danish]. København: Gyldendal.

J ohnson, D., \&J ohnson, R. T. (1988). Cooperativelearning. Transforming education. Context Institute. Retrieved from http://www.context.org/iclib/ic18/

J ohnson, D. W., \&J ohnson, R. T. (1994). Cooperative, competitive, and individualistic learning (4th ed.). Needham Heights, MA: Allyn and Bacon.

J onassen, D. H. (2000). Toward a design theory of problem-solving. Educational Technology Research and Development, 48(4), 63-85.

J onassen, D. H. (2006). On the role of concepts in learning and instructional design. Educational Technology Research \& Development, 54(2), 177-196.

J onassen, D. H. (2011). Learning to solve problems: A handbook for designing problem-solving learning environments. New York: Routledge.

J onassen, D. H., Carr, C., \&Yueh, H. (2007). Computers as mindtools for engaging learners in critical thinking. TechTrends, 43(2), 24-32. 
J ones, B., Valdez, G., Nowakowski, J ., \& Rasmussen, C. (1994). Designing learning and technology for educational reform. Oak Brook, IL: North Central Regional Educational Laboratory.

Kammerl, R. (2011). Media, Bildungstheory and Didactics. In S.Hillen, T. Sturm \& I. Willbergh (Eds.). Challenges facing contemporary didactics: Diversity of students and the role of new media in teaching and learning (pp. 129-142). Münster: Waxmann.

Kerres, M. (2005). Gestaltungsorientierte Mediendidaktik und ihr Verhältnis zur Allgemeinen Didaktik [Configuration oriented media didactics and its relationship to general didactics, in German]. In P. Stadtfeld, \& B. Dieckmann (Eds.), Allgemeine Didaktik im Wandel (pp. 214-234). Heilbrunn: Klinkhardt Verlag.

Kerres, M. (2006). Didaktisches Design und E-Learning [Didactic design and ELearning; in German] (pp. 156-182). In D. Miller (Ed.), eLearning. Eine multiperspektivische Standortbestimmung. Bern: Hauptverlag.

Kerres, M. (2007). Zum Selbstverständnis der Mediendidaktik —eine Gestaltungsdisziplin innerhalb der Medienpädagogik [The self conception of media didactics - a discipline within media education; in German]? In W. Sesink, M. Kerres, \&H. Moser (Eds.), J ahrbuch Medien-Pädagogik 6. (pp. 161178). Wiesbaden: VS Verlag für Sozialwissenschaften.

Kerres, M., \&de Witt, C. (2004). Pragmatismus als theoretische Grundlage für die Konzeption von e-learning [Pragmatism as theoretical platform for the conception of e-learning; in German]. In H. O. Meyer, \&D. Treichel (Eds.), Handlungsorientiertes Lernen und eLearning (pp. 77-99). München: Oldenburg.

Klafki, W. (2002). Characteristics of critical-constructive didaktik. In B. B. Gundem \& S. Hopmann (Eds.), Didaktik and / or curriculum. an international dialogue (pp. 307-330). Frankfurt: Peter Lang.

Kron, F. W. (2008). Grundwissen der Didaktik [Basic principles in didactics; in German]. (5th ed.). München, Basel: Reinhardt.

Kron, F. W., \&Sofos, A. (2003). Mediendidaktik. Neue Medien in Lehr- und Lernprozessen [Media didactics. New Media in teaching and learning processes; in German]. München: Ernst Reinhardt.

Lave, J ., \&Wenger, E. (1991). Situated learning: Legitimate peripheral participation. Cambridge: Cambridge University Press. 
Lodgaard, E., Melbye, P. E., Torgersen, G.-E., \& Loeng, S. (2001). Voksenpedagogikk i kompetansesamfunnet [Adult education in a competence society; in Norwegian]. Skarnes: Compendius.

Lorenzen, M. (2008). Chaos theory and education. The information literacy land of confusion. Retrieved from http://www.informationliteracy.net/2008/04/chaos-theory-and-education.html

Mandl, H., Gruber, H., \& Renkl, A. (2002). Situiertes Lernen in multimedialen Lernumgebungen [Situated learning in multimedia learning environments; in German]. In L. J . Issing \& P. Klimsa (Eds.), Information und Lernen mit Multimedia und Internet (pp. 139- 148). (2nd ed.). Weinheim: Beltz Psychologie Verlags Union.

Mayer, R., \& Moreno, R. (1998). Split-attention effect in multimedia learning: Evidence for dual processing systems in working memory. J ournal of Educational Psychology, 90(2), 312-320.

McLeod, S. (2008). Information processing. Simply Psychology. Retrieved from http:// www.simplypsychology.org/information-processing.html

Morrison, G., Ross, S., \& Kemp, J . (2004). Designing effective instruction. Hoboken, NJ : J ohn Wiley \& Sons, Inc.

Niegemann, H. M., Domagk, S., Hessel, S., Hein, A., Hupfer, M., \& Zobel, A. (2008). Kompendium multimodales Lernen [Compendia multimodal learning; in German]. Berlin: Springer.

Nipper, K. (ND). Curriculum development project: The adventures of J asper Woodbury series. University of Georgia. Retrieved from http://jwilson.coe.uga.edu/ emt668/EMT668.Folders.F97/Nipper/EMAT6690/ Jasper/Jasper.html

Oakes, J ., \&Lipton, M. (1999). Teaching to change the world. Boston: MoGraw-Hill College.

Østerud, S., \& Knudsen, M. (2009). Rom og tid i didaktiske modeller [Space and time in didactics models; in Norwegian]. In S. Østerud (Ed.), Enter veien mot en IKTdidaktikk. Oslo: Gyldendal Akademisk.

Palloff, R. M., \& Pratt, K. (2007). Building online learning communities - effective strategies for the virtual classroom. San Francisco, CA: Wiley.

Picciano, A. G., \& Seaman, J . (2007). K- 12 online learning. Survey of U.S. school district administrators. Retrieved from http://sloanconsortium.org/ publications/survey/K-12_06 
Picciano, A. G., \& Seaman, J . (2009). K- 12 online learning. A 2008 follow-up of the survey of U.S. school district administrators. Retrieved from http:// www.onlinelearningsurvey.com/reports/k-12-online-learning.pdf

Piskurich, G. M. (2006). Rapid instructional design: Learning ID fast and right. San Francisco, CA: J ohn Wiley and Sons.

Prensky, M. (2001). Digital game-based learning. New York: McGraw-Hill.

Reigeluth, C. M. (Ed.) (1987). Instructional theories in action. Lessons illustrating selected theories and models. London: Lawrence Erlbaum Associates.

Reigeluth, C. M. (1999). The elaboration theory: Guidance for scope and sequence decisions. In C.M. Reigeluth (Ed.), Instructional-design theories and models: A new paradigm of instructional theory (Volume II, pp. 425-454). Hillsdale, NJ : Lawrence Erlbaum Assoc.

Rowland, G. (1992). What do instructional designers actually do? An initial investigation of expert practice. Performance Improvement Quarterly, 5(2), 65-86.

Schank, R. (1997). Virtual learning: A revolutionary approach to building a highly skilled workforce. New York: McGraw-Hill.

Schneider, W., \& Shiffrin, R. M. (1977). Controlled and automatic human information processing: 1. Detection, search, and attention. Psychological Review, 84, 1-66.

Schüpbach, E., Guggenbühl, U., Krehl, C., Siegenthaler, H., \& Kaufmann-Hayoz, R. (2003). Didaktischer Leitfaden für E-Learning [Didactic code of practice for elearning; in German]. Bern: h.e.p.-Verlag.

Schulz, W. (1997). Die lehrtheoretische Didaktik [Learning theoretical didactics; in German]. In H. Gudjons (Ed.), Didaktische Theorien (pp. 35-56). Hamburg: Winkelverlag.

Seminole County Public Schools (2014). Retrieved from http:// www.scps.k12.fl.us/Home.aspx

SFIB (2007). Educaguides. Guides zur Beratung und Unterstützung von Lehrpersonen, Ausbilderinnen und Ausbildern beim Einsatz von ICT im Unterricht. Schweizerische Fachstelle für Informationstechnologien im Bildungswesen. Retrieved from http://guides.educa.ch/sites/default/files/Didaktik_d_kurz.pdf

Smith, P. L., \& Ragan, T. J . (1999). Instructional design (2nd ed.). New York: Merrill, Macmillan Publishing Company. 
Squire, K., J ohnson, C., \& Bichelmeyer, B.A. (1998). Personalized independent learning systems in high technology environments. Proceedings of selected research and development presentations at the 1998 National Convention of the Association for Educational Communications and Technology. St. Louis, MO, USA. (ERIC Document Reproduction Service No. ED423873).

Straka, G. A., \& Macke, G. (2002). Lern-lehrtheoretische Didaktik [Learning-teaching theoretical didactics; in German]. Münster: Waxmann.

Sweller, J . (1999). Instructional design in technical areas. Camberwell, Victoria, Australia: Australian Council for Educational Research.

Terhart, E. (2009). Didaktik. Eine Einführung [Dicatics. An introduction; in German]. Stuttgart: Reclam.

Thomas, D., \& Brown, J . S. (2011). Createspace, quest to learn. A new culture of learning. Retreived from www.Q2L.org

Tulodziecki, G. (2005). Zur Situation der Medienpädagogik in der Bundesrepublik Deutschland [About the situation of media education in the German Federal Republic]. Retrieved from http:// www.medienpaed.com/Documents/medienpaed/11/tulodziecki05-1.pdf

Tulodziecki, G., \&Herzig, B. (2010). Mediendidaktik. Medienverwendung in Lehr- und Lernprozessen [The use of media in teaching and learning]. München: kopäd.

Tulodziecki, G., \& Herzig, B. (2004). Handbuch Medienpädagogik. Band 2: Mediendidaktik. Medien in Lehr- und Lernprozessen [Handbook of Media education]. Volume 2: Media didactics. Media in teaching and learning processes; in German]. Stuttgart: Klett Cotta.

von Humboldt, W. (2000). Theory of Bildung. In I. Westbury, K. Riquarts \& S. Hopmann (Eds.), Teaching as a reflective practice: The German didaktik tradition (pp. 57-61). Mahwah, N.J .: Lawrence. Erlbaum Associates.

Westbury, I., Riquarts, K., \& Hopmann, S. (2000). Teaching as a reflective practice: The German didaktik tradition. Mahwah, N.J .: Lawrence Erlbaum Associates.

\section{Athabasca University $\mathbf{a}$}

